\title{
Survivorship and Inheritance Rights for Same-Gender Couples: Relevance to Social Workers
}

\author{
Jessica Cordero \\ Darrel Montero \\ Teisha Portee \\ Renee Spears \\ Vicki Stevenson \\ Erica Tatum
}

\begin{abstract}
Californians voted in November 2008 to ban the right to same-gender marriage in California. This paper summarizes data on changes in societal attitudes relative to homosexuals, same-gender couples, and their civil rights as reflected in Gallup and Princeton Survey Research Associates International poll data over the years through 2011. These findings report deeply entrenched and enduring divisions in American attitudes toward the rights and status of same-gender couples. Although historically a majority of Americans has consistently opposed same-gender marriage, Americans increasingly recognize the need to extend equality to same-gender couples in the form of employment rights, inheritance rights, Social Security, and health insurance benefits. This article explores existing and proposed policies regarding the rights of same-gender couples. In addition, it examines the implications and opportunities for advocacy by social workers who face the challenge of navigating the legal and personal obstacles that arise when their client's same-gender relationships are not sanctioned by law.
\end{abstract}

Keywords: Homosexuality, same-gender unions, same-gender marriages, domestic partnerships, marriage

On November 4, 2008, Californians went to the polls in record numbers to strike down the right to same-gender marriage. The passage of Proposition 8 was a major setback not only for the gay and lesbian community, but indeed, some would argue for all Americans. This emotionally charged decision indicates the volatile nature of the attitudes towards gay and lesbian rights in America. The rate at which same-gender couples are forming and publicly declaring their relationships, as evidenced by Census data, is growing. In August 2011, the U.S. Census Bureau counted 646,464 same-gender households headed by same-gender couples - up from approximately 358,000 in 1990 (Yen, 2011).

More significant, however, is the increasing urgency in which gay men and lesbians are asserting their rights to the same partnership benefits that married heterosexual couples enjoy. There are over 1,100 federal benefits awarded to heterosexual couples when they marry that cannot be taken advantage of by same-gender couples, including social security survivor benefits, coverage under Family and Medical Leave Act, and the right to file joint tax returns (Robinson, 2011).

Jessica Cordero, Teisha Portee, Renee Spears, Vicki Stevenson, and Erica Tatum are all former MSW students; and Darrel Montero, Ph.D., is an Associate Professor, all in the School of Social Work at Arizona State University in Phoenix.

Copyright (c) 2011 Advances in Social Work Vol. 12 No. 2 (Fall 2011), 345-362 
While states like Vermont and New Jersey have begun granting same-gender couples domestic partnerships, many conservative Americans have fought back, even proposing a constitutional amendment that would specifically define marriage as a heterosexual institution and limit the ability of gay couples to receive benefits like Social Security, health insurance, employee benefits, and survivorship rights (Hunter, 2010). This push for a constitutional amendment has occurred at both state and federal levels. However, even some notable conservatives have supported the rights of same-gender couples to the institution of marriage (Barnes, 2010; Becker, 2009; Totenberg, 2010).

Although television shows such as Will and Grace, Queer as Folk, and Modern Family have brought gay issues and gay characters into more and more American homes, American attitudes toward homosexuality remain deeply divided. This is perhaps nowhere more clearly seen than in relationship to the question of whether gay partners should enjoy the same legal and economic protections of married heterosexual couples (Olson, 2010). This article examines the evolving opinions of the American public from 1977 to 2011 by asking a cross-section of Americans the following questions: (1) Do you think marriages between homosexuals should or should not be recognized by the law as valid, with the same rights as traditional marriages?; (2) Do you think homosexuals should or should not have equal rights in terms of job opportunities?; (3) Do you think there should or should not be... inheritance rights for gay spouses?; (4) Do you think there should or should not be... Social Security benefits for gay spouses?; and (5) Do you think there should or should not be... health insurance benefits for gay spouses? This study will advance our understanding of the attitudes towards the rights of same-gender couples and thereby provide empirically based ammunition for social workers as advocates of social change.

\section{LITERATURE REVIEW}

\section{Gay Rights, Domestic Partnerships, and Equality}

The promise of "equal protection of the law" is addressed in the U.S. Constitution, and echoed in numerous significant pieces of legislation including the Americans with Disabilities Act and the Civil Rights Act of 1991. These Acts serve to prohibit discrimination based on disability status, race, and gender. However, laws that would prohibit discrimination based on sexual orientation remain largely unaddressed, specifically concerning Social Security, health insurance, employee benefits, and survivorship rights. In the absence of such federal and state guidelines, gay men and lesbians are often vulnerable to discrimination and differential treatment.

In New York, with the passage of same-gender marriage, the ability to add a spouse to an employer's plan may be one of the more significant financial benefits. Same-gender employees are taxed on the health benefits of their partner because their status is not recognized by the federal government. However, same-gender married couples no longer will have to pay state tax (Bernard, 2011c; 2011d). It is interesting to note that the issue of rights for same-gender couples is currently being determined at the state level, which further adds to divide in public opinion on this issue. 
Great strides have been made towards encouraging more tolerant public attitudes towards gay and lesbian issues; however, more concise federal guidelines are needed in order to ensure that the writings of the U.S. Constitution shift from promises to guarantees. Closely monitoring the past and present trends of Americans' attitudes towards gay and lesbian issues allows social workers a close appraisal of the complexity of public sentiment and the political and social climate for future policy changes and advocacy for the equal rights of same sex couples. These data provide empirically based ammunition for social workers as advocates of social change.

Questions about equality for gay men and lesbians are nowhere more contested than in regard to the issue of same-gender marriage, civil unions, or same-gender partnerships. In 1999, the Vermont Supreme Court granted gay and lesbian couples benefits identical to those of heterosexual married couples, ushering in a wave of similar legislation in California, Connecticut, Massachusetts, Iowa, and New Jersey (Cole, 2009). These states' actions reignited a national debate on same-gender marriage and the rights of samegender couples. While many conservatives objected to gay men and lesbians receiving what they considered special legal protection, gay activists criticized the unequal status of civil unions, which they felt denied them access to a social institution that symbolizes full membership in American society.

The literature suggests that Americans' attitudes toward homosexuality are distinct from their opinions about whether gay men and lesbians should be allowed civil rights like that of marriage or domestic partnership. While the majority of Americans are reluctant to identify homosexuality as "moral," most Americans are unwilling to restrict the civil liberties of gay men and lesbians (Badgett, 2009; Pan, Meng, \& Zhou, 2010). A period of more tolerant public attitudes towards homosexuality emerged in the 1970s, but encountered a setback with the upswing of conservatism beginning in the 1980s through the 1990s. Since 2000, support for expanding gay men and lesbians' civil liberties has rapidly increased (Harms, 2011).

\section{The Defense of Marriage Act and Homosexuality as an Acceptable Lifestyle}

In 1996, then-President Clinton signed the Defense of Marriage Act into law. The Defense of Marriage Act (or DOMA) grants states the right to refuse recognition of marriages or unions between people of the same gender-even if those marriages or unions were legally performed in another state (Defense of Marriage Act, 1996). Further, DOMA prohibits the federal government from recognizing any state-performed samegender marriage or union. Drafted in anticipation of states like Massachusetts, that eventually granted marriage rights to gay and lesbian couples, DOMA has been criticized as governing morality and overstepping constitutional rights like due process (Feigen, 2004). Some DOMA supporters, however, feel that DOMA does not go far enough and have proposed a constitutional amendment known as the Federal Marriage Amendment that would specifically define marriage in the United States as a heterosexual institution.

With the passage of laws such as the Defense of Marriage Act of 1996 and the fight to legalize gay marriages, the legal status of same-gender couples has become more salient. The most significant barrier to the American public's acceptance of same-gender 
marriage or civil unions is institutionalized heterosexism or the "set of ideas, intuitions, and relationships that make the heterosexual family the societal norm while rendering homosexual/queer families 'abnormal' and 'deviant'” (Lind, 2004, p. 23). Despite the cultural and legal entrenchment of institutionalized heterosexism, there have been some gains in rights for gays and lesbians - most significantly, the acknowledgment by a few states that gay men and lesbians have the right to their partners' health and insurance benefits and the right to adopt. In addition, many private companies have voluntarily incorporated nondiscrimination clauses into their own practices and codes of ethics.

\section{Same-Gender Partnerships and Marriage Rights for Gay and Lesbian Couples}

In 2000, Vermont became the first state to legalize civil unions for same-gender couples. Civil unions in Vermont and other states grant same-gender couples benefits similar or even identical to those of marriage, but allow states to "reserve" the institution of marriage for heterosexual couples (Hunter, 2010). Although support for civil unions has increased throughout the years, public opinion (among both gay-rights activists and conservative religious groups) is still somewhat divided (Hertz \& Doskow, 2011; Newton, 2010).

The institution of marriage is a social, legal, and religious construct that has evolved over centuries. Religious or orthodox conservatives who oppose allowing gay men and lesbians the right to marry cite Biblical justifications and believe that marriage is for the purpose of procreation. Advocates of same-gender marriage believe that all citizens have the right to marry and should not be discriminated against on the basis of their sexual orientation. Additionally, supporters of same-gender marriage point to how the institution of marriage in the United States has changed over time. For example, interracial marriage was only decriminalized in 1967, and many gay-rights activists liken discrimination against same-gender couples to that previously exercised against couples of different races (Frank \& McEneaney, 1999).

Those who support same-gender marriage rights for gay men and lesbians want all couples - gay and straight - to share the status and rights associated with marriage (Greene, 2011). According to the U.S. General Accounting Office, marital status is a factor in more than 1,100 federal laws, and marriage imparts nearly 1,400 federal and state benefits including hospital visitation, adoption, and inheritance rights (Robinson, 2011). A key consideration in this debate is whether civil unions or same-gender marriage would be better suited as a path for gay men and lesbians to achieve social and economic parity with their heterosexual counterparts. Some critics believe that permitting civil unions and not marriage would be equivalent to classifying same-gender relationships as second class. Thus, this manuscript shall examine Americans' attitudes toward the rights and benefits for same-gender couples over the past 3 decades. 


\section{METHODS}

\section{Design of the Sample for Personal Surveys}

The findings of this study were based on published opinion polls from the Gallup Organization (2011a; 2011b; 2011c; 2011d) and Princeton Survey Research Associates (2004; 2008). The design of the sample for personal (face-to-face) surveys was that of a replicated area probability sample down to the block level in the case of urban areas and down to segments of townships in the case of rural areas. After stratifying the nation geographically and by size of community according to information derived from the most recent census, over 350 different sampling locations were selected on a mathematically random basis from within cities, towns, and counties that have, in turn, been selected on a mathematically random basis.

The procedures just described were designed to produce samples that approximate the adult civilian population (aged 18 and older) living in private households (that is, excluding those in prisons, hospitals, hotels, and religious and educational institutions, as well as those individuals living on reservations or military bases) and, in the case of telephone surveys, households with access to a telephone. Survey percentages may be applied to census estimates of the size of these populations to project percentages onto the numbers of people. Furthermore, the manner in which the sample was drawn also produces a sample that approximates the distribution of private households in the United States; therefore, survey results can also be projected onto the number of households.

\section{Limitations of the Study}

As in all survey research, there are questions of social desirability response bias, reliability, validity, and margin of error issues. Davis (1971) and others have indicated that reliability and validity issues are some of the most challenging concerns encountered in social research. The Gallup Organization has addressed these issues on a continuous basis since 1935. They are constantly improving their methodological techniques through testing question wording and sampling design to improve reliability and validity of their survey results. A complete methodological appendix outlining these efforts can be found in Gallup and Newport (2010).

\section{RESULTS}

\section{Attitudes toward the Legal Validity of Same-Gender Marriage}

The issue of whether marriage between same-gender couples should be recognized by law has had a history of controversy and divided opinion in America. From 1996 to 2011, a national cross section of Americans was asked the following question: "Do you think marriages between homosexuals should or should not be recognized by the law as valid, with the same rights as traditional marriages?” (see Table 1).

The results reveal support increasing dramatically from 1996 to 2011 for recognizing homosexual marriages by law as valid. In 1996, approximately 1 in 4 Americans supported same-gender marriages. Whereas, by 2011, a full majority (53\%) reported that 
these marriages should be recognized by law as being valid, with the same rights as traditional marriage.

Table 1: Attitudes toward the Legal Validity of Same-Gender Marriage, 1996-2011

\begin{tabular}{lccc}
\hline & Should Be Valid & Should Not Be Valid & No Opinion \\
Year & $\%$ & $\%$ & $\%$ \\
\hline 1996 & 27 & 68 & 3 \\
1999 & 35 & 62 & 3 \\
2004 & 42 & 55 & 3 \\
2005 & 37 & 59 & 4 \\
2006 & 39 & 58 & 4 \\
2006 & 42 & 56 & 2 \\
2007 & 46 & 53 & 1 \\
2008 & 40 & 56 & 4 \\
2009 & 40 & 57 & 3 \\
2010 & 44 & 53 & 3 \\
2011 & 53 & 45 & 3 \\
\hline
\end{tabular}

Question: "Do you think marriages between homosexuals should or should not be recognized by the law as valid, with the same rights as traditional marriages?"

a Data reported twice in one year indicate that the question was asked twice in that year.

Notes: Figures may not total $100 \%$ because of rounding. For each table, authors have reported all data which were collected by the Gallup Organization. However, it is important to note that these organizations did not conduct the same survey every single year, which explains the occasional gaps in the data reported year to year.

Source: Poll data compiled by the Gallup Organization (2011a).

\section{Attitudes toward Equal Employment Rights for Gay Men and Lesbians}

Americans have appeared to be historically fair-minded on the issue of equal rights in terms of job opportunities for gay men and lesbians. Between 1977 and 2008, a cross section of Americans was asked the following question: "Do you think homosexuals should or should not have equal rights in terms of job opportunities?” (see Table 2). The number of Americans who supported equal employment rights for gay men and lesbians ranged from a low of nearly 6 in 10 Americans in 1977 to a high of nearly 9 in 10 Americans when the question was last posed in 2008. 
Table 2: $\quad$ Attitudes toward Equal Employment Rights for Gay Men and Lesbians, 1977-2008 ${ }^{\mathrm{a}}$

\begin{tabular}{lcc}
\hline & Yes, Should & No, Should Not \\
Year & $\%$ & $\%$ \\
\hline 1977 & 56 & 33 \\
1982 & 59 & 28 \\
1989 & 71 & 18 \\
1992 & 74 & 18 \\
1993 & 80 & 14 \\
1996 & 84 & 12 \\
1999 & 83 & 13 \\
2001 & 85 & 11 \\
2002 & 86 & 11 \\
2003 & 88 & 9 \\
2003 & 88 & 10 \\
2004 & 89 & 8 \\
2005 & 87 & 11 \\
2006 & 89 & 9 \\
2007 & 89 & 8 \\
2008 & 89 & 8 \\
\hline 0450 & & 8 \\
\hline
\end{tabular}

Question: "Do you think homosexuals should or should not have equal rights in terms of job opportunities?”

${ }^{\text {a }}$ Data reported twice in one year indicate that the question was asked twice in that year.

Notes: Figures may not total $100 \%$ because of rounding. For each table, authors have reported all data which were collected by the Gallup Organization. However, it is important to note that these organizations did not conduct the same survey every single year, which explains the occasional gaps in the data reported year to year.

Source: Poll data compiled by the Gallup Organization (2011b). 


\section{Attitudes toward Inheritance Rights, Social Security, and Health Insurance Benefits for Gay and Lesbian Spouses}

From the mid-1990s to the late-2000s, a cross section of the American public was asked the following three questions: (a) "Do you think there should or should not be inheritance rights for gay spouses, 1994-2009?" (see Table 3); (b) "Do you think there should or should not be... Social Security benefits for gay spouses, 1994-2008?” (see Table 4); and (c): "Do you think there should or should not be... health insurance and other employee benefits for gay spouses, 1997-2009?” (see Table 5).

Table 3: $\quad$ Attitudes toward Inheritance Rights for Gay and Lesbian Spouses, 1994-2009

\begin{tabular}{lccc}
\hline & $\begin{array}{c}\text { Should } \\
\%\end{array}$ & $\begin{array}{c}\text { Should Not } \\
\%\end{array}$ & $\begin{array}{c}\text { Don't Know } \\
\%\end{array}$ \\
\hline 1994 & 61 & 30 & 9 \\
1996 & 61 & 29 & 10 \\
1997 & 62 & 30 & 8 \\
1998 & 59 & 33 & 8 \\
2000 & 62 & 28 & 10 \\
2004 & 60 & 30 & 10 \\
2008 & 74 & 20 & 6 \\
2009 & 73 & 24 & 4 \\
\hline
\end{tabular}

Question: "Do you think there should or should not be... inheritance rights for gay spouses?”

Notes: Figures may not total $100 \%$ because of rounding. For each table, authors have reported all data which were collected by the Gallup Organization and Princeton Survey Research Associates International. However, it is important to note that these organizations did not conduct the same survey every single year, which explains the occasional gaps in the data reported year to year.

Source: Poll data compiled by Princeton Survey Research Associates International (2008) [Newsweek poll conducted by Princeton] and the Gallup Organization (2011c). 
Table 4: $\quad$ Attitudes toward Social Security Rights for Gay and Lesbian Spouses, 1994-2008

\begin{tabular}{lccc}
\hline & $\begin{array}{c}\text { Should } \\
\%\end{array}$ & $\begin{array}{c}\text { Should Not } \\
\%\end{array}$ & $\begin{array}{c}\text { Don't Know } \\
\%\end{array}$ \\
\hline 1994 & 55 & 39 & 6 \\
1996 & 48 & 43 & 9 \\
1997 & 57 & 37 & 6 \\
1998 & 52 & 41 & 7 \\
2000 & 54 & 38 & 8 \\
2004 & 55 & 36 & 9 \\
2008 & 67 & 27 & 6 \\
\hline
\end{tabular}

Question: "Do you think there should or should not be... Social Security benefits for gay spouses?”

Notes: Figures may not total $100 \%$ because of rounding. For each table, authors have reported all data which were collected by Princeton Survey Research Associates International. However, it is important to note that these organizations did not conduct the same survey every single year, which explains the occasional gaps in the data reported year to year.

Source: Poll data compiled by Princeton Survey Research Associates International (2004; 2008) [Newsweek poll conducted by Princeton].

The results reveal some striking trends and remarkable consistency. Over the decade in which these questions were posed, approximately 6 in 10 Americans, in the mid-1990s, consistently supported gay men and lesbians' rights to inheritance, Social Security, and employee benefits from their partners. This support increased modestly to nearly 7 in 10 Americans by the late 2000s. 
Table 5: $\quad$ Attitudes toward Health Insurance Benefits for Gay and Lesbian Spouses, 1997-2009

\begin{tabular}{lccc}
\hline & $\begin{array}{c}\text { Should } \\
\%\end{array}$ & $\begin{array}{c}\text { Should Not } \\
\%\end{array}$ & $\begin{array}{c}\text { Don't Know } \\
\%\end{array}$ \\
\hline 1997 & 59 & 36 & 5 \\
1998 & 58 & 37 & 5 \\
2000 & 58 & 34 & 8 \\
2004 & 60 & 33 & 7 \\
2008 & 73 & 23 & 4 \\
2009 & 67 & 30 & 2 \\
\hline
\end{tabular}

Question: Do you think there should or should not be... health insurance and other employee benefits for gay spouses?

Notes: Figures may not total $100 \%$ because of rounding. For each table, authors have reported all data which were collected by the Gallup Organization and Princeton Survey Research Associates International. However, it is important to note that these organizations did not conduct the same survey every single year, which explains the occasional gaps in the data reported year to year.

Source: Poll data compiled by Princeton Survey Research Associates International (2004; 2008) [Newsweek poll conducted by Princeton] and the Gallup Organization (2011d).

\section{DISCUSSION}

Marriage is a private and public demonstration of commitment that affords couples a range of benefits and protections. When a state denies same-gender couples the right to a legal marriage, these couples are denied many of the same benefits (Gallagher, 2010). American attitudes toward homosexuality are sharply divided and, at times, even contradictory. These data reveal that a majority of Americans hold nondiscriminatory attitudes toward homosexuality. For example, half of Americans in 2011 think marriage between homosexuals should be recognized by the law as valid (Gallup Organization, 2011a). It is important to note that for the first time since this question was first posed in 1996, a full majority of Americans (53\%) support same-gender marriage.

Historically, change has occurred due to a cultural watershed or ideological change. That is, as Americans' opinions about other marginalized groups, such as African Americans and women, became more accepting, these favorable opinions generalized to other marginalized groups, including gay men and lesbians (Schroeder, 2004). Other possible explanations for increased tolerance of homosexuality could be a greater 
awareness of gay and lesbian issues in the media and larger numbers of Americans who say that they know at least one person who is gay (Brewer, 2007).

Although an individual's race, gender, and disability status are protected from discrimination by federal and state laws, gay men and lesbians remain vulnerable to differential treatment and discrimination. This legal reality does not appear to be in line with a majority of Americans' views on homosexuality. For example, as reported in Table 2 as recently as 2008, nearly 9 in 10 Americans supported equal employment rights for gay men and lesbians.

When it comes to inheritance rights, Americans appear willing to allow same-gender couples the same benefits married couples enjoy: the ability to leave property to a surviving spouse. For example, New York couples who choose to marry will be first in line to inherit their spouses' assets. This is true, even if there is no will (Bernard, 2011b). If there are children, the spouse receives $\$ 50,000$ and half of the estate. The children then split the remaining monetary assets. The surviving spouse also chooses what to do with the remains of the deceased. However, not all rights are granted. Couples still neither file federal joint income taxes nor inherit the retirement benefits of their partner (Greene, 2011).

With regard to Social Security and employee health benefits, Americans are more reluctant to extend these benefits to same-gender couples. Vives (2010) contends that the overall concern of benefits rights should be based more on economic equality than even marriage equality. Indeed, it is possible to argue that Americans are cautiously conservative with regard to same-gender rights, but are less willing to grant same-gender couples the right to legally marry (Winenke \& Hill, 2009). However, it is interesting to note that nearly 6 in 10 (58\%) Fortune 500 companies offer coverage to employees with same-gender partners. Similarly, McGough (2010), Bernard (2011a), Lutgens and Trast (2011), and National Conference of State Legislatures (2011) also report increasing benefits rights for same-gender partners.

\section{IMPLICATIONS FOR SOCIAL WORK PRACTICE}

As social workers, we often think of same-gender marriage and related issues as fairly contemporary. However, current social work practice and policy is guided by the definition of family adopted over 3 decades ago in 1981 by the National Association of Social Workers (NASW): "A grouping that consists of two or more individuals who define themselves as a family and who over time assume those obligations to one another that are generally considered an essential component of family systems" (Bern-Klug, 2010, p. 188).

Most of the injustices that gay men and lesbians experience are not linked to high profile national events, and their stories do not usually make the evening news. However, every day, gay men and lesbians experience the impact of discrimination on the job due to the fact that they lack comparable employee health, welfare, and retirement benefits for their same-gender partners. Gay and lesbian couples' differential legal status in the United States means that social workers must understand both how discrimination affects 
same-gender couples and their children as well as the urgency with which these couples need greater protection under the law.

Social workers have developed a variety of resources which provide best practice techniques that can be employed while working with same-gender couples. For example, Ambrosio, Heffernan, and Shuttlesworth (2011) developed a framework of general social work practice techniques dealing with same-gender marriage. Gardner (2010) examines the Council on Social Work Education's (CSWE) challenges regarding employment benefits for gay and lesbian partners. He further observes that same-gender couples face these challenges as they grow old, requiring social workers to create programs to meet their specific needs, to persuade for systematic change, and to make social workers aware of their own assumptions. Additionally, Hardina, Middleton, Montana, and Simpson (2007) have developed culturally sensitive practice models and theories that empower this specific population.

Social workers often draw from allied professions such as psychology. In this vein, the American Psychological Association (2011) has developed practice guidelines based on 21 principles for working with lesbian, gay, and bisexual clients. Self-determination is a core value for social workers. Towards this end, same-gender couples should make their own decisions after all options are made known to them.

In healthcare settings, several authors have discussed the role of social workers specializing in palliative care and end-of-life planning for same-gender couples. Altilio, Otis-Green, and Farrell (2011) note that despite the legality of same-gender marriage in a number of states, social workers need to assess the environment of their clients' healthcare setting. This is because even well-executed documents may not meet the requirements of specific state laws. Thus, we have seen that a variety of best practices have been developed for numerous social work settings that deal with same-gender couples; for example, end-of-life palliative facilities. Collins (2011), for example, reports on the mandatory recognition of gay couples by hospitals. Significantly, the presidential memorandum enacted on January 18, 2011 outlaws discrimination based on gender identity and requires more than 6,200 hospitals to inform patients of their rights to visitors of their choosing, with more than 35 million admissions yearly.

According to the National Resource Center for Permanency and Family Connections (2011), there are a variety of best practices available for meeting the needs of samegender couples and the complexity of gay marriage issues. In addition, Mallon (2008) provides a series of best practice principles working with same-gender couples. NASW mandates that social workers have a critical role in assisting individuals and their families regarding their options in the face of legal barriers to marriage, civil unions, same-gender partnerships, inheritance and survivorship, and employees' benefits as they affect this population. On a regular basis, NASW offers a series of continuing education seminars on topics for social workers and family law for same-gender couples (NASW, 2011).

Drawing from the numerous best practice techniques presented above as well as those available from allied professions, schools of social work throughout the country are now in a better position to design a comprehensive curriculum that employs these direct practice techniques to work with same-gender couples. 
Figueira-McDonough (1993) describes policy practice as the "neglected side of social work interventions" (p. 179). She articulates four approaches to policy practicelegislative advocacy, reform through litigation, social action, and social policy analysiswhich we apply here in hopes of inspiring such work.

\section{Legislative Advocacy}

Given how deeply divided American opinion about gay rights is, an advocacy approach is particularly pertinent. Past inequities in American history-slavery, segregation, and women's suffrage-all required some form of legislation to set right, even when corrective action was unpopular at the time.

Social workers, equipped with this knowledge, could serve their clients by working at local, state, and federal levels to secure some form of partnership rights for same-gender couples. Indeed, social workers familiar with the findings reported here may be in a unique position to advocate for legislative change by actively promoting the extension of inheritance rights and employee benefits to same-gender couples.

\section{Reform through Litigation}

When weighing the potential applicability of the reform-through-litigation approach, social workers should become familiar with the laws and the patience to see test cases through to their conclusion. Reform through litigation is nevertheless a viable option for social workers interested in advocating for their same-gender clients' right to inheritance, Social Security, and employee health insurance benefits, as well as to receive many of the other benefits associated with legal marriage.

In Perry v. Schwarzenegger (2010), which challenged the federal constitutionality of Proposition 8, expert witnesses were utilized to provide critical perspectives on the similarity between heterosexual and same-gender relationships. Cott (as cited in Shih, 2010) argued that marriage has become more gender neutral, and that same-gender marriage is capable of fulfilling the purposes of marriage from an economic perspective. In her testimony, UCLA social work professor Peplau (as cited in National Center for Lesbian Rights, 2010) agreed that the quality and stability of same-gender relationships are similar to those of heterosexual relationships, noting that most couples marry to gain physical, psychological, and social benefits.

Social workers are in a unique position to collect data on the nature of relationships between same-gender couples and determine their similarity or distinctiveness from heterosexual relationships. This is how social workers can bolster their credibility through systematic empirical research to address these specific issues surrounding samegender couples.

\section{Social Action}

Social workers could employ this community-based approach on a local level by establishing ongoing dialogue within their community about same-gender couples' need for legal recognition and by mobilizing central community players for change. 
Knowledge of public opinion data like those presented here could aid social workers in their work toward legal protection of same-gender relationships using the social action approach. Specific findings in this article-in particular, the data presented on equal employment rights and support for gay spouses' inheritance, Social Security, and health insurance rights - may be important "leverage points" social workers can use to advocate for expanding same-gender couples' rights. Knowing that a majority of Americans is sympathetic to the plight of same-gender spouses - who may be unable to inherit property when their partner dies or visit their ailing spouse in the hospital—could provide much needed common ground in a conversation or public forum on gay rights.

\section{Social Policy Analysis}

The fourth approach is a valuable tool because it provides social workers with the skills necessary to closely read and understand social policy. By applying analytical lenses like self-determination and equity, social workers are better equipped to understand pending legislation that directly affects their clients.

Social workers experience many ethical dilemmas related to same-gender couples, including how public opinion greatly influences this population. State and national policies continue to evolve, and the consequences of these policies have the potential to affect same-gender couples. This point may be relevant when working not only with gay and lesbian clients, but with family members of these clients whose feelings about homosexuality ultimately affect the entire family system.

The National Association of Social Workers (NASW) (2008) has established clear guidelines for social work with gay and lesbian clients: "Same-gender sexual orientation should be afforded the same respect and rights as other-gender orientation” (p. 5). In terms of advocacy, the NASW is "committed to working toward the elimination of prejudice and discrimination based on sexual orientation, both inside and outside the profession" and is "working to help enact antidiscrimination legislation at the national, state, and local levels as well” (p. 1).

All social workers have a responsibility to understand the unique circumstances of their clients. Knowledge, training, and awareness are crucial in order to serve each client effectively. Finally, social workers are uniquely trained to empower their clients who are dealing with profound questions regarding same-gender marriage.

\section{References}

Altilio, T., Otis-Green, S., \& Farrell, B. R. (2011). Oxford textbook of palliative social work. London: Oxford University Press.

Ambrosio, R., Heffernan, J., \& Shuttlesworth, G. (2011). Social work and social welfare: An introduction. Belmont, CA: Wadsworth Publishing.

American Psychological Association. (2011). Practice guidelines for LGB clients:

Guidelines for psychological practice with lesbian, gay, and bisexual clients.

Washington, DC: Author. Retrieved from

http://www.apa.org/pi/lgbt/resources/guidelines.aspx 
Badgett, M. V. L. (2009). When gay people get married: What happens when societies legalize same-sex marriage. New York: New York University Press.

Barnes, R. (2010, June 14). Olson surprises many conservatives by seeking to overturn gay-marriage ban. Washington Post [online]. Retrieved from http://www.washingtonpost.com/wpdyn/content/article/2010/06/13/AR2010061305057.html

Becker, J. (2009, August 18). A conservative's road to same-sex marriage advocacy. The New York Times [online]. Retrieved from http://www.nytimes.com/2009/08/19/us/19olson.html?pagewanted=all

Bern-Klug, M. E. (2010). Transforming palliative care in the nursing home: The social work role. New York: Columbia University Press.

Bernard, T. S. (2011a, May 21). For gay employers, an equalizer. The New York Times, p. B1.

Bernard, T. S. (2011b, June 27). How gay marriage will change couples' financial lives. The New York Times [Web log post]. Retrieved from http://bucks.blogs.nytimes.com/2011/06/24/how-gay-marriage-will-change-couplesfinancial-lives/

Bernard, T. S. (2011c, July 5). Same-sex spouses in New York will get health insurance. The New York Times [Web log post]. Retrieved on http://bucks.blogs.nytimes.com/2011/07/05/same-sex-spouses-in-new-york-will-gethealth-insurance/

Bernard, T. S. (2011d, August 3). Tax changes for gay married New Yorkers. The New York Times [Web log post]. Retrieved from http://bucks.blogs.nytimes.com/2011/08/03/tax-changes-for-gay-married-newyorkers/

Brewer, P. R. (2007). Value war: Public opinion and the politics of gay rights. Lanham, MD: Rowman \& Littlefield.

Cole, D. (2009, July 2). The same-sex future. Georgetown Law Faculty Publications and Other Works. Paper 3.

Collins, M. (2011, January 26). Memorandum protects same-sex couples in hospitals [newsletter]. New York: Diversity Best Practices. Retrieved from http://www.diversitybestpractices.com/news-articles/memorandum-protects-samesex-couples-hospitals

Davis, J. A. (1971). Elementary survey analysis. Englewood Cliffs, NJ: Prentice Hall.

Defense of Marriage Act, Pub. L. No. 104-199, 110 Stat. 2419 (1996).

Feigen, B. (2004). Same-sex marriage: An issue of constitutional rights not moral opinions. Harvard Women's Law Journal, 27, 345-355. 
Figueira-McDonough, J. (1993). Policy practice: The neglected side of social work intervention. Social Work, 38, 179-188.

Frank, D. J., \& McEneaney, E. H. (1999). The individualization of society and the liberalization of state policies on same-sex sexual relations, 1984-1995. Social Forces, 77, 911-943.

Gallagher, M. (2010). Why accommodate? Reflections on the gay marriage culture wars. Northwestern Journal of Law and Social Policy, 5, 260-273.

Gallup, A. M., \& Newport, F. (2010). The Gallup poll: Public opinion 2010. Lanham, MD: Rowman \& Littlefield.

Gallup Organization. (2011a). Same-sex couples recognized by law. Retrieved from http://www.gallup.com/poll/117328/Marriage.aspx

Gallup Organization. (2011b). Equal rights. Retrieved from http://www.gallup.com/poll/1651/Gay-Lesbian-Rights.aspx

Gallup Organization. (2011c). Inheritance rights for gay and lesbian domestic partners. Retrieved from http://www.gallup.com/poll/1651/Gay-Lesbian-Rights.aspx

Gallup Organization. (2011d). Health insurance and other employee benefits for gay and lesbian domestic partners. Retrieved from http://www.gallup.com/poll/1651/GayLesbian-Rights.aspx

Gardner, D. S. (2010, June). Practice with LGBT elders. Aging Times [e-newsletter]. Retrieved from http://www.cswe.org/CentersInitiatives/GeroEdCenter/GECPublications/agingtimes/ 36510/41380/41382.aspx

Greene, K. (2011, July 9). Headaches for same-sex couples. Wall Street Journal [online]. Retrieved from http://online.wsj.com/article/SB10001424052702303982504576428341158786506.ht $\underline{\mathrm{ml}}$

Hardina, D., Middleton, J., Montana, S., \& Simpson (2007). An empowering approach to management social service organizations. New York: Springer Publishing.

Harms, W. (2011). Americans move dramatically toward acceptance of homosexuality, survey finds. University of Chicago News [online]. Retrieved http://news.uchicago.edu/article/2011/09/28/americans-move-dramatically-towardacceptance-homosexuality-survey-finds

Hertz, F., \& Doskow, E. (2011). Making it legal: A guide to same-sex marriage, domestic partnerships \& civil unions ( $2^{\text {nd }}$ ed.). Berkeley, CA: Nolo.

Hunter, S. (2010). Effects of conservative religion on lesbian and gay clients and practitioners: Practice implications. Washington, DC: NASW Press.

Lind, A. (2004). Legislating the family: Heterosexist bias in social welfare policy frameworks. Journal of Sociology and Social Welfare, 31(4), 21-35. 
Lutgens, C., \& Trast, C. R. (2011, July 13). Employee benefit considerations for marriage by same-sex couples in New York. Kramer Levin Naftalis \& Frankel Employee Benefits Alert [Memorandum]. Retrieved from http://www.martindale.com/members/Article_Atachment.aspx?od=404239\&id=1317 918\&filename=asr-1317922.Marriage.pdf

Mallon, G. P. (Ed.). (2008). Social work practice with lesbian, gay, bisexual, and transgender people. New York: Routledge.

McGough, M. (2010, April 14). Same-sex social security benefits? Not while DOMA lives. Los Angeles Times [online]. Retrieved from http://opinion.latimes.com/opinionla/2010/04/samesex-social-security-benefits-notwhile-doma-lives.html

National Association of Social Workers. (2008). Code of ethics. Washington, DC: Author. Retrieved from http://www.socialworkers.org/pubs/code/code.asp

National Association of Social Workers. (2011). Social workers and family law issues for same-sex couples. Washington, DC: Author. Retrieved from http://www.socialworkers.org/ce/online/lunchtime/lcourses/home.aspx

National Center for Lesbian Rights. (2010, January 10). NCLR's legal director Shannon Minter on Perry $v$ Schwarzenegger proceedings, day 3 [Web log post]. Retrieved from http://nclrights.wordpress.com/2010/01/13/nclrs-legal-director-shannon-minteron-perry-v-schwarzenegger-proceedings-day-3/

National Conference of State Legislatures. (2011). States offering benefits for same-sex partners of state employees. Author. Retrieved from http://www.ncsl.org/default.aspx?tabid=1631

National Resource Center for Permanency and Family Connections. (2011). LGBTQ issues \& child welfare. New York: Author. Retrieved http://www.hunter.cuny.edu/socwork/nrcfcpp/info_services/lgbtq-issues-and-childwelfare.html

Newton, D. E. (2010). Same-sex marriage: A reference handbook. Santa Barbara, CA: ABC-CLIO.

Olson, T. B. (2010, January 18). The conservative case for gay marriage: Why same-sex marriage is an American value. Newsweek, 48-54.

Pan, P. L., Meng, J., \& Zhou, S. (2010). Morality or equality? Ideological framing in news coverage of gay marriage legitimization. The Social Science Journal, 47(3), 630-645.

Perry v Schwarzenegger, Case No. C 09-2292 VRW (U.S. District Court for the Northern District of California, 4 August 2010).

Princeton Survey Research Associates International. (2004). American jobs and foreign competition—Newsweek poll—Final topline results [Data file]. Princeton, NJ:

Author. 
Princeton Survey Research Associates International. (2008). American jobs and foreign competition—Newsweek poll—Final topline results [Data file]. Princeton, NJ: Author.

Robinson, B. A. (2011). Marriage: Same-sex and opposite-sex. Legal and economic benefits of marriage. Retrieved from http://www.religioustolerance.org/mar_bene.htm

Schroeder, M. (2004). Changing social attitudes in the United States: Increasing acceptance of homosexuals. University of Wisconsin-La Crosse Journal of Undergraduate Research, 7. Retrieved from http://www.uwlax.edu/urc/JURonline/PDF/2004/schroeder.pdf

Shih, G. (2010, January 12). Same-sex marriage case, day 2: History lessons. The New York Times [Web log post]. Retrieved from http://bayarea.blogs.nytimes.com/2010/01/12/same-sex-marriage-case-day-2-historylessons/

Totenberg, N. (2010). Ted Olson, gay marriage’s unlikely legal warrior. National Public Radio. Retrieved from http://www.npr.org/2010/12/06/131792296/ted-olson-gaymarriage-s-unlikely-legal-warrior

Vives, R. (2010, April 12). Equal social security benefits for same-sex couples urged. Los Angeles Times [online]. Retrieved from http://articles.latimes.com/2010/apr/12/local/la-me-social-security12-2010apr12

Winenke, C., \& Hill, G. J. (2009). Does the 'marriage benefit” extend to partners in gay and lesbian relationships? Journal of Family Issues, 30(2), 259-289.

Yen, H. (2011, September 27). Census: Many gay couples say they're married-even if they technically aren't. MSNBC [online] Retrieved from http://www.msnbc.msn.com/id/44690992/ns/us news-life/?gt1=43001

\section{Author's note:}

Address correspondence to: Dr. Darrel Montero, Arizona State University School of Social Work, MC 3920, 411 North Central Avenue, Ste. 800, Phoenix, AZ 85004-0689.

Email: Darrel.montero@asu.edu 